\title{
VLADIMIR NABOKOV's LoLITA AND THE MERITED-RESPONSE ARGUMENT
}

\author{
- Anna Głąb -
}

\begin{abstract}
In attempting to answer whether Nabokov's Lolita can be described as an unethical novel, the author ponders on what basis one could make such a determination. At (1) the author analyzes the merited-response argument offered by Gaut (and previously Hume and Carroll), which provides a conceptual framework for the resolution of the controversy surrounding Lolita. Based on this analysis, (2) the author decides what constitutes the novel's ethical foundation and what (3) prescriptions and (4) responses can follow from it.
\end{abstract}

Keywords: Nabokov, Lolita, Gaut, the merited-response argument, ethics, Booth, Rorty.

Published online: 30 November 2021

In Vladimir Nabokov's novel Lolita some find outrage, and some find delight. The outraged feel indignant with the author for having given a voice to a paedophile, Humbert Humbert, who, after her mother's death takes custody of the twelve-year-old Dolores Haze and exploits her sexually. Those outraged include Lionel Trilling, who after the novel's publication in 1953 wrote: "We find ourselves the more shocked when we realise that, in the course of reading the novel, we have come virtually to condone the violation it [novel] presents (...) we have been seduced into conniving in the violation, because we have permitted our fantasies to accept what we know to be revolting." ${ }^{1}$ Several years later Wayne Booth underscores "the reader's inability to dissociate himself from a vicious center of consciousness presented to him with all of the seductive self-justification of skilful rhetoric." 2 The delighted, leaving the book's morality aside, speak of its brilliant rhetoric the protagonist employs to seduce them, and sometimes they let him. Among them many praise a narration full of changing modes of consciousness, illusion, imaginations, and dreams, as well as the poetic of a night dream that is "full of impossible yearnings, repeated frustrations, fantastic coincidences, improbable wish-fulfilments." ${ }^{3}$ Doubtless, as Colin McGinn notes, one of the novel's main characters is the language itself with its force of expression and way of concealing the reality. Moreover, Humbert

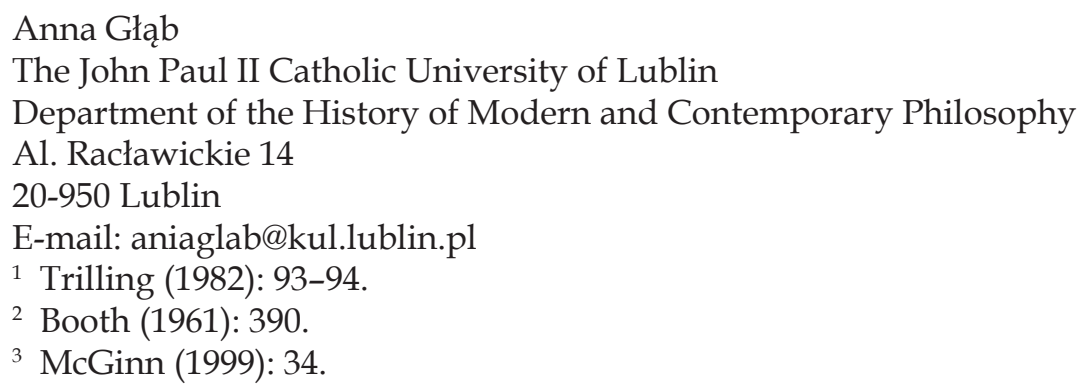


Humbert's infatuation with Lolita is inextricably joined to his love of language: "reality is sleekly eclipsed and vanquished by its description." 4 To the cognoscenti, Lolita is also a tragic tale of love ${ }^{5}$ - love for someone to whose feelings one is blind, seeing only what one feels. It also records, as John Hollander puts it, the author's "love affair with the romantic novel" 6 or, as Nabokov himself confesses in the afterword, with the English language. ${ }^{7}$ According to Nabokov's American publisher and connoisseur, Alfred Appel, many of Lolita's readers may be more perplexed by Humbert Humbert's use of language and plot than with his violations of Lolita and of the law. ${ }^{8}$ It is also understood as a "parody of love stories." 9 Appel, however, also notes how the most extraordinary thing in Lolita is how Nabokov, against our will, forces us to take Humbert's side. Humbert makes the reader "his accomplice in both statutory rape and murder." ${ }^{10}$ Others stress that Lolita is a tale of the (im)possibility of love and the price to pay for solipsism and sexism, as well as the "quest for immortality through art." ${ }^{11}$ All these reactions, immensely complex as one can see, together compose the audience's response to Nabokov's work. Let us emphasize: they are all responses to one and the same work. How can one and the same novel possibly elicit such a variety of responses? Did Nabokov realize the scandal his novel would bring?

The situation becomes convoluted also because of Nabokov's stance on morality. In the already mentioned afterword he observes:

I am neither a reader nor a writer of didactic fiction, and, despite John Ray's assertion, Lolita has no moral in tow. For me a work of fiction exists only insofar as it affords me what I shall bluntly call aesthetic bliss, that is a sense of being somehow, somewhere, connected with other states of being where art (curiosity, tenderness, kindness, ecstasy) is the norm. ${ }^{12}$

Here, Nabokov appears to voice the manifesto of an author who represents autonomous and purely aesthetic trends in art and with them the appeal of "art for art's sake." Not yielding to the moral force of the creations of Fyodor Dostoevsky or Thomas Mann, ${ }^{13}$ in his afterword Nabokov claims that their novels, which he calls a Literature of Ideas, are "topical trash coming in huge blocks of plaster that are carefully transmitted from age to age until somebody comes along with a hammer and takes a good crack at Balzac, at Gorki, at Mann." ${ }^{14}$ In the introduction to Lectures on Literature he states that a great writer "can be considered: he may be considered as a storyteller, as a teacher, and as

\footnotetext{
4 Ibidem: 35.

5 Ibidem: 36.

6 See Edelstein (2008): 43.

7 See Nabokov (1991b): 380-386.

8 Appel (1991b): 3.

9 Appel (1991a): 489.

10 Appel (1967): 224.

11 Edelstein (2008): 43.

12 Nabokov (1991a): 384

13 Levine (1995): 36.

${ }^{14}$ Nabokov (1991b): 384.
} 
an enchanter," 15 and only when "the three facets of the great writer - magic, story, lesson - are prone to blend in one impression of unified and unique radiance, (...) the magic of art may be present in the very bones of the story, in the very marrow of thought."16 Nabokov does not want his books to be read through an ethical lens, though he does admit that a good writer has also to be a teacher. He, therefore, accepts the possibility that great literature can have a moral impact on its readers. How, though, does he understand it, aside from perceiving the relationship between art and morality as a sort of game? ${ }^{17}$

It would appear that the morality from which he withholds his assent is the judging of what his novel presents from the perspective of a higher system of established and unequivocal ethical values, those "blocks of plaster" that can be subjected to revaluation in the light of the dominant mores. It is the didacticism which sees in literary works their moralizing or educational side, ignoring the aesthetic side. It is depriving art of its autonomy by describing it in categories different than art itself uses or represents. Nabokov does not hold such morality in high regard, though he fails to appreciate that what he refers to as an "aesthetic bliss" - paving the way to such states of existence as tenderness, goodness or even curiosity, which, as Peter Levine writes when undertaking reflection on Lolita, also can be counted among virtues ${ }^{18}$ - is a direct expression of the morality of art. For art can take us toward goodness, compassion, empathy or tenderness, ${ }^{19}$ but it can also evoke disgust or aversion. Art is subject to the categories of ethical violation, for it can be read - in Martha Nussbaum's words - as a "paradigm of moral activity." ${ }^{20}$ This way of reading, according to her, "requires the cultivation of perception and responsiveness: the ability to read a situation, singling out what is relevant for thought and action. This active task is not a technique; one learns it by guidance rather by a formula." 21 In this way literature, in becoming material for the study of human acts in their moral aspect, lays open before the reader a space for asking difficult questions. Nabokov may want no part in didacticism or moralizing, but he can hardly avoid morality. After all, in his own words: "Beauty plus pity - that is the closest we can get to a definition of art." 22

In this text I would like to examine what responses Nabokov's novel elicits from the reader, other than the ones I mentioned in the beginning. Can Nabokov's work be described as unethical? On what basis? At (1) I want to analyze what Berys Gaut calls the merited-response argument. This is going to be my source of terminology for deciding in what light to view Lolita. Following on the most important constituents of Gaut's argu-

\footnotetext{
${ }^{15}$ Nabokov (1980): 5.

16 Ibidem: 6.

17 See Grygiel (2016).

${ }^{18}$ See Levine (1995): 43-44.

${ }^{19}$ See "Tenderness is spontaneous and disinterested; it goes far beyond empathetic fellow feeling. Instead, it is the conscious, though perhaps slightly melancholy, common sharing of fate. Tenderness is deep emotional concern about another being, its fragility, its unique nature, and its lack of immunity to suffering and the effects of time. Tenderness perceives the bonds that connect us, the similarities and sameness between us. It is a way of looking that shows the world as being alive, living, interconnected, cooperating with, and codependent on itself. Literature is built on tenderness toward any being other than ourselves. It is the basic psychological mechanism of the novel." Tokarczuk (2019): 24-25. ${ }^{20}$ Nussbaum (1990a): 148.

${ }^{21}$ Nussbaum (1990b): 44.

${ }^{22}$ Nabokov (1980): 251.
} 
ment, (2) I will decide on what makes up the novel's ethical attitude, (3) its prescriptions and (4) the responses. I will attempt to demonstrate the impossibility of responding only to the aesthetic side due to the answerability of the content to moral judgment. Nor would responding only to the ethical side be the full response that the work merits. I will strive to demonstrate that Lolita ought to be read as a novel whose great aesthetic merit lies in how it elicits from the reader responses that lead to multifaceted analysis and to a sharpening of one's sensitivity to evil. Simultaneously, I wish to emphasize that in this text I will not be dealing with the philosophical quality of Gaut's argument or the debate surrounding it. My goal is instead to be able to examine Nabokov's novel in its light following some necessary accommodation.

\section{The merited-response argument}

Before pronouncing on whether Lolita is an unethical novel, we first have to decide what in it is to be encompassed by such ethical evaluation. When examining the ethical status of a literary work, do we look at the consequence only or at something more intrinsic? Consequences can vary, and all depends on the reader, whether critical or naïve. One cannot always place an objective answer to the question of the ethics of a work on such foundations. There will always be different, subjective responses. Could the two elements - intrinsic value and the reader's response - not be combined, though? Berys Gaut holds that the ethical value of a work lies primarily in its intrinsic ethical value. ${ }^{23}$ It includes ethical properties of the attitude the work can reflect or manifest - an attitude making us inclined to infer judgments touching on moral good or evil. In evaluating the ethical value of a work one evaluates first of all the quality of the point of view, the perspective contained in it or the perspective it leads to. This quality manifests itself through the manner of narration (e.g., character description) and how the characters respond to situations they find themselves in (such as acceptance or repulsion). We then look at what cognitive (e.g., the deprivation of views, the imparting of evil inclinations) or affective (emotional) responses the work elicits from the reader. A work is thus ethically good or evil depending on the attitude that is inscribed in it and on the prompting of a specific attitude (response). Gaut refers to this as the merited response argument. ${ }^{24}$ It has a second part answering the question of how the ethical value of a work interacts with its aesthetic value: "a work is aesthetically flawed in so far as it possesses aesthetically relevant ethical flaw and aesthetically meritorious in so far as it possesses an aesthetically relevant ethical merit." 25 Ethical flaws and merits are intrinsic flaws and merits and not ethically evil or good effect of the work on the reader; hence, intrinsic flaws or merits in the attitude the work manifests to the audience. ${ }^{26}$

\footnotetext{
${ }^{23}$ Gaut (2007): 9.

${ }^{24}$ Its first form was presented by Gaut in: Gaut (1998): 182-200. N. Carroll also invoked this argument (see Carroll (2000): 350-387).

${ }^{25}$ Gaut (2007): 229.

${ }^{26}$ The original version of this argument was discussed by David Hume in Of the Standard of Taste: "where vicious manners are described, without being marked with the proper characters of blame and disapprobation; this must be allowed to disfigure the poem, and to be a real deformity. I cannot, nor is it proper I should, enter into such sentiments" (Hume (2004): 330). His reference is primarily
} 
What, however, is the relationship between the attitude manifested by the work and the response? The attitude inscribed in the work constitutes at the same time the prescribed response to it. For example, through its attitude a Greek tragedy prescribes katharsis, by presenting a monstrous thing a horror story prescribes a response of fear, and Jane Austen's novels prescribe the admiration of their heroines. What happens when the reader does not respond with the prescribed attitude? For example, when one does not respond with excitement to de Sade's depictions of sexual violence? Gaut believes the response prescribed by a given work does not necessarily have to be our actual response. What we are dealing with in such a case is the work being defeated by its own aesthetic defect. The defect is that the reader has good reasons for not responding in the prescribed way. In this way literature can manifest in its own attitude intrinsic ethical flaws that are aesthetically significant, and the reader may not want to respond as prescribed due to not approving of the prescription. Such a work does not merit a response of acceptance from the audience. Sometimes, however, the attitudes taken in literary works prescribe a varied range of often contradictory responses. For example "a novel that apparently prescribes its readers to be amused at a character's undeserved suffering, but that does so in order to show up the ease with which the reader can be seduced into callous responses." ${ }^{27}$ Different authors employ different methods. Some are transparent in their choice of means and goals. Others employ seduction strategies. They often do so in order to elicit deeper awareness or bring out a lack of sensitivity. Thus, the attitude in this sense appears to be something different from prescriptions. This appearance is superficial and lasts only until we accept the additional premise that: "prescriptions, like attitudes, come in a hierarchy, with higher-order prescriptions taking lower-order ones as their objects." 28 Thus, my amusement at the character's suffering is apparently the prescribed response, but there is also a higher-order prescription that this amusement must be regarded as callous, and therefore as unmerited. ${ }^{29}$ The prescription can encompass amusement as a response describable as a lack of sensitivity. Amusement will thus not be a merited response, because the work does not merit it, due to also issuing a higher-order prescription. In Gaut's view, "talk of prescriptions from now on should be construed as involving the complete set of relevant prescriptions that a work makes towards fictional events." 30

What can be the responses we give to prescriptions manifested in the attitude? Gaut defines responses very broadly. When reading Jane Austen's novels, we are not merely invited to imagine the characters and their relationships with each other. Inscribed in their attitude is the prescription that we are to respond emotionally to what happens to the characters, to wish them well or to support the ideal of love that they hold dear. The concept of response, therefore, spans a broad range of states, from approval (or

to the affective response, and he believes that aesthetic pleasure ought not to be derived from a work that encourages us to indulge in immoral feelings. According to Hume, such feelings we ought not to pursue when the work is suggesting that we embrace them. The reader's response must be adequate to what is presented in the work - it must be justified, merited (Gaut (2007): 228).

${ }^{27}$ Gaut (2007): 230.

${ }^{28}$ Ibidem.

${ }^{29}$ Ibidem.

${ }^{30}$ Ibidem. 
disapproval) of the characters' conduct, through affection (or aversion), to a desire that everything end well for the characters or reflection on what the future may have in store for them. Sometimes, however, the responses are not appropriate, which means they are not merited. This does not mean, of course, that all readers have to respond identically to the prescriptions reflected in the work's attitude. Responses are appropriate when they are responses to the work taken as a whole, aesthetically and ethically. Gaut asserts that when we read a horror story and are afraid of an innocent character who reminds us of our own terrifying uncle and only for that reason, then our fear is not merited. Such a response is thus not appropriate. Accordingly, our response is appropriate when it is grounded in a full understanding of the presented character's history. Only on this condition can our admiration or aversion be merited and appropriate. If the reader shows dissatisfaction with the character's appropriate conduct or reacts with laughter to the character's sadistic sentiments or conduct, then such responses will themselves be liable to ethical censure. In such a case it seems the work has failed to meet its purpose contained in the attitude, for it has elicited an unmerited response. Gaut believes this should be regarded among the aesthetic flaws of literary works.

In presenting certain events as hilarious, a comedy prescribes laughter as the response. However, if it prescribes that the readers laugh at soulless cruelty, that is hardly comical. Gaut asserts that the attitude taken by such a work contains a defect, and one of ethical significance at that. If a work prescribes compassion for characters who do not deserve it because of the evil done to others, then such characters do not merit compassion. As a result, we can once again speak of aesthetic failure. If, on the other hand, a given work encourages us to take part in a character's joy that is by all means meritorious, then the work succeeds. The same is the case when we are invited to feel compassion for characters' innocent suffering. Responses must be justified in the sense that the work must merit them.

\section{The novel's attitude}

What is the prescribed response to Humbert Humbert in Nabokov's Lolita? Is it compassion or aversion? The two are closely interlinked. Responses are meant to follow from prescriptions manifested in the novel's attitude, i.e., its perspective. Accordingly, it will be expedient to first subject the attitude to a rigorous examination. Let us take note that Nabokov's narration has a certain built-in limitation due to being provided only by Humbert Humbert. Since he alone gets to present us, the readers, with a picture of the situation, we cannot be sure to be dealing with a full picture that coincides with the objective reality. Next, it must be borne in mind that Humbert is addressing his hypothetical jury or us readers who are about to judge him. Accordingly, he provides an account of his life in which he reminds us of the baggage of experiences he carries. He refers to that experience as a "tangle of thorns." 31 From his perspective, the tangle explains his actions or even justifies them. Apparently, this is supposed to build in us a response grounded in compassion. He thus reminisces about the loss of his mother as an infant

${ }^{31}$ Nabokov (1991a): 84. I mark the quotations on the main text. 
(she died at a picnic, struck by lightning), depriving him of motherly warmth and care, and about living through his first teenage infatuation with Annabel, who was to die of typhus four months later. Humbert wonders if his life was not at that point marked with its first scratch, that being the desire which he had felt for Annabel, which could not be consummated and which resurfaced years later through his love for Lolita. As we can see, Humbert attempts to rely on conventional defenses - an unhappy childhood and romantic trauma.$^{32} \mathrm{He}$ then moves to an argument of cultural relativism and asserts that there was no prohibition against sexual intercourse with young girls in ancient Egypt, Israel or India. He recalls Dante's loss of his mental composure for a nine-year-old Beatrice, and Petrarca's for a twelve-year old Laura. He proceeds to discuss how he initially resisted his urges: "While my body knew what it craved for, my mind rejected my body's every plea. One moment I was ashamed and frightened, another recklessly optimistic. Taboos strangulated me" (93). He overcame the taboo, however, by taking recourse to rationalizations such as: "Hugh Broughton, a writer of controversy in the reign of James the First, has proved that Rahab was a harlot at ten years of age. (...) Lepcha old men of eighty copulate with girls of eight, and nobody minds" (94). One can be baffled by the appearance of this argument in the narration. What does Nabokov want to achieve with it? Is his purpose not to demonstrate to us the irrelevance of all philosophical ponderings of good and evil? Nonetheless, when confronted with Humbert's actions we conclude that they were in fact evil. He himself describes a series of highly immoral acts, each time concluding that they were full of baseness. ${ }^{33}$ On the other hand, Humbert begs for understanding and empathy from his readers.

When Humbert begins to describe his relations with Lolita, this is what he tells the readers:

I want my learned readers to participate in the scene I am about to replay; I want them to examine its every detail and see for themselves how careful, how chaste, the whole wine-sweet event is if viewed with what my lawyer has called, in a private talk we have had, 'impartial sympathy' (130).

What he encourages the readers to see in his first congress with Lolita is primarily sweetness and innocence. However, it is difficult to see what he wants us to see. He envelopes this argument in a bubble wrap of poetic circumstances:

I entered a plane of being where nothing mattered, save the infusion of joy brewed within my body. What had begun as a delicious distension of my innermost roots became a glowing tingle which now had reached that state of absolute security, confidence and reliance not found elsewhere in conscious life. (...) Lolita had been safely solipsized. The implied sun pulsated in the supplied poplars; we were fantastically and divinely alone; I watched her, rosy, gold-dusted, beyond the veil of my controlled delight (...) I had ceased to be Humbert the Hound, the sad-eyed degenerate

\footnotetext{
32 See Levine (1995): 38.

${ }^{33}$ McGinn (1999): 37.
} 
cur clasping the boot that would presently kick him away. (...) In my self-made seraglio, I was a radiant and robust Turk, deliberately, in the full consciousness of his freedom, postponing the moment of actually enjoying the youngest and frailest of his slaves (133).

He expounds his own perspective and claims to have never harmed the child in any way. In possessing Lolita he solipsized her, and thus only his own feelings were what mattered to him. He goes on to assert: "What I had madly possessed was not she, but my own creation, another, fanciful Lolita - perhaps, more real than Lolita" (135). He objectifies her, as we can see elsewhere: "She would be (...) wagging her tiny tail, her whole behind in fact as little bitches do" (233). In Lolita Humbert does not see a person vested with dignity but an only object that can be used for his own goals.

Later, Humbert discovers that Lolita is not a virgin, providing him with another avenue for his defense: "Frigid gentlewomen of the jury! I had thought that months, perhaps years, would elapse before I dared to reveal myself to Dolores Haze; but by six she was wide awake, and by six fifteen we were technically lovers. I am going to tell you something very strange: it was she who seduced me" (204). In this manner Humbert wants to make the jury perceive him as someone who deserves compassion and understanding. However, the reader can identify a certain lack of proportion between Humbert's creation of himself (as a congenial man suffering from an erotic obsession with a child) and the acts described by him, the meaning of which is clear. This dissonance appears to expose Humbert as an unreliable narrator - because of his striking solipsism - and to prompt a search for something more than meets the eye, ${ }^{34}$ i.e., close observation of all that which he did not clearly state, and which remains between the lines or has been communicated in a perfunctory, elliptical way. This unreliability, as McGinn notes, need not, however, be a flaw of Nabokov's work. Instead, it can be a veiled hint as to the prescribed attitude to Humbert. This vehicle for this prescription would be precisely his failure to be conscientious in his narration. It is in his distorted view of what he writes about that the reader can discover bias, inaccuracy, and falsehood..$^{35}$ Thus, in bringing attention to the narrator's unreliability, the novel prescribes a cautious way of dealing with those moments in which Lolita herself is recalled. For it is her, the victim, and not Humbert Humbert claiming that all he did, he did out of his love for her. After Humbert rapes his adoptive daughter for the first time in the hotel, Lolita reproaches him thus:

"You chump", she said, (...) "You revolting creature. I was a daisy-fresh girl, and look what you've done to me. I ought to call the police and tell them you raped me. Oh, you dirty, dirty old man" (212).

He appears to realize what he has done and be fraught with remorse:

\footnotetext{
${ }^{34}$ Peter Levine believes this internal solipsism in Humbert's narration to be something that makes the proper reading of Nabokov's work more difficult. He regards it as a flaw inhibiting the presentation of all facts, especially those exceeding Humbert's own perspective (see Levine (1995): 39).

${ }^{35}$ McGinn (1999): 39.
} 
This was an orphan. This was a lone child, an absolute waif, with whom a heavy-limbed, foul-smelling adult had had strenuous intercourse three times that very morning. Whether or not the realization of a lifelong dream had surpassed all expectation, it had, in a sense, overshot its mark - and plunged into a nightmare (211).

The realization, nevertheless, is short-lived, for two sentences later he admits: "somewhere at the bottom of that dark turmoil I felt the writhing of desire again, so monstrous was my appetite for that miserable nymphet" (212). Only then does Lolita find out her mother is dead (she died in front of her own house crushed by a car on the same day she read her husband's scribblings about her daughter). From then on Lolita knows she is at Humbert's mercy and may even believe him to have killed her mother:

At the hotel we had separate rooms, but in the middle of the night she came sobbing into mine, and we made it up very gently. You see, she had absolutely nowhere else to go (214).

The attitude of Nabokov's novel therefore appears to be built on contradiction, for though Humbert realizes that his conduct has been evil, he always finds a way of justifying it. Is there anything else in the attitude that could assist us with its correct identification?

\section{Prescriptions in the novel}

In keeping with Gaut's argument, if the incentives to empathize with Humbert are decisive of the whole attitude of the novel, we have a right to conclude that - since we cannot empathize with him - the novel contains an aesthetic flaw. This is because of encouraging a response that is not morally appropriate. The question remains whether Nabokov's novel, on the balance of its attitude, contains encouragement to respond to Humbert's acts with understanding. Our responses will be appropriate only when we have understood all of Humbert's history and thus - to speak directly - have not rejected it with outrage but read the tale from cover to cover. This will happen once we have read all of the prescriptions properly. In keeping with the merited-response argument, a novel can formulate prescriptions of a lower and a higher order. Aside from the lower-order prescriptions (formulated by Humbert in addressing the jurors to make them want to justify or understand him), there are also higher-order prescriptions in Lolita. There are, as I see it, three kinds of them. The first kind is given by the fictitious author of the preface to Nabokov's novel, Doctor John Ray Jr. Let us ponder his prescriptions first. He writes:

in this poignant personal study there lurks a general lesson; the wayward child, the egotistic mother, the panting maniac - these are not only vivid characters in a unique story: they warn us of dangerous trends; they point out potent evils. Lolita should make all of us - parents, social workers, educators - apply ourselves with still greater vigilance and vision to the task of bringing up a better generation in a safer world (82). 
Why would Nabokov put an introduction by a fictitious psychiatrist in his novel? Is that not a porte-parole for himself? Not at all! We do know that Nabokov detested moralizing, and that is what the introduction is. Is he not already parodying a potential moralizing approach to his novel? Peter Levine observes that the introduction shows clearly that the readers ought to avoid the method of reading implied by Doctor Ray. John Ray's name itself evokes an $18^{\text {th }}$-century British naturalist who proposed a very influential system of classification of insects (which, as we know, was one of Nabokov's life-long interests). Ray, according to Levine, thinks in terms of simplification and classification of human conduct so as to cram it within some type of monochromatic statistics. Who is Humbert in the good doctor's eyes? Levine observes that from Ray's diagnosis Humbert emerges as nothing more or less than "species: pederast; genus: sex maniac; family: egoist; order: sinner; class: human being." ${ }^{36}$ Nabokov certainly does not view his protagonist in the same light. He is not interested in pursuing Humbert's history as an example of someone else's scientific theory. ${ }^{37}$ Instead, John Ray is a fictitious persona whose approach Nabokov clearly ridicules, certainly not intending us to - as McGinn points out - infer such a simple and direct ethical lesson from his novel as he proposes in the introduction. ${ }^{38}$

Should we not, however, look to Nabokov himself for prescriptions? How are we to understand his character's story, if he as the author deals derisively with an attempt at classification? Levine recalls Nabokov's statement from an interview in which the journalist asked him whether Humbert's character could be interpreted as a touching person, and the author responded:

I would put it differently: Humbert Humbert is a vain and cruel wretch who manages to appear "touching." That epithet, in its true, tear-iridized sense, can only apply to my poor little girl..$^{39}$

In his opinion, our compassion should go not to Humbert but to Lolita, his favorite character. ${ }^{40}$ Her fate should be the basis for our tenderness. This is what Nabokov says of his novel in the interview, though he does not let it on in the book itself; hence, this prescription is not part of the novel. Our investigation is worth continuing, though. The third type of higher-order prescriptions are, in my opinion, the rare signals coming from Humbert's conscience, as well as Lolita's equally rare utterances about her situation. Let us trace them both.

Humbert endeavours to persuade us, the readers, that his intention had been for Lolita to have as good a time as possible. He describes Lolita as: "a child herself, showing another child some of her few accomplishments, such as for example a special way of jumping rope" (232). And he reminisces about:

\footnotetext{
${ }^{36}$ Levine (1995): 37.

${ }^{37}$ Levine notes that Freudian psychoanalysis was the butt of Nabokov's ridicule in this novel (see Ibidem: 44).

${ }^{38}$ McGinn (1999): 38.

${ }^{39}$ Nabokov (1973): 94.

40 Boyd (1991): 237. Nabokov professed to have two favorite characters among those he had created - Lolita and Pnin (the protagonist of a novel under the same title, Nabokov (1993)).
} 
flashing a smile to the shy, dark-haired page girl of my princess and thrusting my fatherly fingers deep into Lo's hair from behind, and then gently but firmly clasping them around the nape of her neck, I would lead my reluctant pet to our small home for a quick connection before dinner (233).

Levine observes that the fatherly fingers firmly clasping around Lolita's neck tell all too much about what the situation looked like from her point of view, which certainly was not the best time in her life. ${ }^{41}$ Elsewhere Humbert recollects providing Lolita with a weekly allowance, which he "paid to her under condition she fulfill her basic obligations" (252). He writes that "only very listlessly did she earn her three pennies - or three nickels - per day" (252). From this we can surmise she was tormented in her relationship with Humbert and not taking the pleasure in it that he did. Besides, she kept "earning" the allowance only because she was hoping to flee. She harboured no doubt as to the nature of their relationship. She called it rape:

"Can you remember," she said, "what was the name of that hotel, you know (...), come on, you know - with those white columns and the marble swan in the lobby? Oh, you know [noisy exhalation of breath] - the hotel where you raped me" (272).

Elsewhere Humbert recollects, en passant: "How sweet it was to bring that coffee to her, and then deny it until she had done her morning duty" (234). Yet elsewhere he writes that as he fell asleep Lolita would break out in tears: "her sobs in the night - every night, every night - the moment I feigned sleep" (243). Near the end of his diary, in turn, he observes: "nothing could make my Lolita forget the foul lust I had inflicted upon her" (352), and:

in order to enjoy my phantasms in peace I firmly decided to ignore what I could not help perceiving, the fact that I was to her not a boy friend, not a glamour man, not a pal, not even a person at all, but just two eyes and a foot of engorged brawn - to mention only mentionable matters (353).

Humbert, though he disregarded the facts, was clearly aware of them: "there were times when I knew how you felt, and it was hell to know it, my little one" (354). Albeit such tiny remarks occur only in between other accounts of Humbert's conduct, they must still be taken into consideration in our attempt to evaluate the whole novel's attitude. They form together a cohesive picture that suggests what Lolita felt in that muzzled relationship with her step-father. They clearly suggest that Dolores Haze had suffering and sorrow inscribed not only in her name but also in every day of her life with the father figure. She was the victim of what the law regards as child abuse. ${ }^{42}$

Remarks emphasizing the child's perspective appear also near the end of the novel, with Humbert finding an already seventeen-year-old Lolita, as Dolly Schiller,

\footnotetext{
${ }^{41}$ Levine (1995): 41.

${ }^{42}$ Ibidem.
} 
pregnant with Dick. Previously, she had managed to escape, only to fall into the hands of another sexual psychopath, Clare Quilty, whom Humbert will later kill. Now she is living in a plank shack in the suburbs and asking her step-father for money. The husband is unaware the step-father had previously abused her sexually. When Lolita tells Humbert she preferred Clare to him, he helps her find the right words: "He broke my heart. You merely broke my life" (347). That is when Humbert begins to realize that "even the most miserable of family lives was better than the parody of incest" (356) which he had given to his adoptive daughter and regarded as the best he could give her. He begins to see in her a separate person, a subject. When she confesses to him her thoughts about death ("You know, what's so dreadful about dying is that you are completely on your own" (353)), he is struck by the realization:

I simply did not know a thing about my darling's mind and that quite possibly, behind the awful juvenile clichés, there was in her a garden and a twilight, and a palace gate - dim and adorable regions which happened to be lucidly and absolutely forbidden to me (353-354).

Just prior to being apprehended by the police, let us note, Humbert experiences his own katharsis. Climbing up in a miner town, he hears the voices of playing children from afar:

Reader! What I heard was but the melody of children at play, nothing but that, and so limpid was the air that within this vapor of blended voices, majestic and minute, remote and magically near, frank and divinely enigmatic - one could hear now and then, as if released, an almost articulate spurt of vivid laughter (...) I stood listening to that musical vibration from my lofty slope, to those flashes of separate cries with a kind of demure murmur for background, and then I knew that the hopelessly poignant thing was not Lolita's absence from my side, but the absence of her voice from that concord (377-378).

Humbert is aware that he has taken Lolita's childhood away from her, feeding to her instead an illusion of adulthood that turned out bitter and distorted. Consequently, in the last words of his diary he makes a confession: "Had I come before myself, I would have given Humbert at least thirty-five years for rape, and dismissed the rest of the charges" (378).

How do we understand Humbert's defense? According to Levine, it ought not to be understood in the ordinary way. Humbert writes that he attempted, in a very conscientious manner, with retrospective verisimilitude (145), to give a faithful recollection of his story. All of this to... condemn himself in the end. In Levine's opinion, if that is the truth, then Humbert's ultimate change of heart is a sincere conversion that deserves our respect. Eventually, Humbert takes on the role of the "educator" he had previously, to Lolita's mother, said he had not become (91). ${ }^{43}$ It appears that if he had

${ }^{43}$ Ibidem: 42. 
truly understood that his story describes acts that were evil, we could believe him that in the end he feels genuine contrition. Levine, however, observes that an argument against accepting Humbert's change of heart as real comes from his quasi-theoretical remark about the purposes of the diary, venturing in the proximity of immoralism. If merely to reference the following:

Unless it can be proven to me (...) that in the Infinite run it does not matter a jot that a North American girl-child named Dolores Haze had been deprived of her childhood by a maniac, unless this can be proven (...), I see nothing for the treatment of my misery but the melancholy and very local palliative of articulate art. To quote an old poet: The moral sense in mortals is the duty / We have to pay on mortal sense of beauty (352).

Is Humbert attempting to find justification in asserting that immoral as his diary may have been, it contains beauty that brings comfort? The purpose of his escape into artistry is to soothe the pain brought about by pangs of guilt. In the final sentences of his diary, he speaks of the "refuge of art" (379), believing it to be "the only immortality you and I may share, my Lolita" (379). Art, however, grants refuge only to a solipsistic Humbert walled off in his obsessions. Certainly not to Lolita, who - as we know from Doctor Ray's introduction - died in childbirth. Nor does art grant such refuge to us, the readers, not even in the form of mitigation of the gravity of the crimes described in Humbert's diary; that ghastliness cannot be assuaged. Does, therefore, Nabokov's novel not lead to any ultimate conclusion? Does its moral attitude not send any clear message as to what we are supposed to think about it and how to respond?

\section{Responses}

Since the prescriptions emerging from Nabokov's novel appear to balance each other out, or at least they are not unequivocal, the safest conclusion would be that Lolita does not encourage any particular response. On the one hand, it puts Humbert's defenses on the table and pleads for an attempt to be made to understand him. On the other hand, it includes references to his self-condemnation and contrition. James Harold believes it to be less than probable that the novel encourages any particular response to Humbert's actions. It would be more apt to say: "the work unsettles us: we do not know how we should respond to the characters and events." 44 Harold is convinced that Lolita in itself, as a literary work, does not, therefore, encourage any specific response to Humbert, be that revulsion or pity, or anything else specific. ${ }^{45}$ This is because Lolita is in a genre of works that do not at all prescribe a response. Its only impact on the reader could be summarized as concern, though not because the novel prescribed being concerned by Humbert's actions but because it gives us suggestions as to how to judge him or what to think of

\footnotetext{
${ }^{44}$ Harold (2006): 267.

${ }^{45}$ Gaut believes that, despite Humbert's unreliability as a narrator, "Nabokov provides several clues that we should not take Humbert's account at the end at face value, nor endorse his views" (Gaut (1997): 199).
} 
him or feel toward him, besides - as Leland de la Durantaye puts it - a disinterested attention to the finesse of the work itself. ${ }^{46}$ Can one, however, read Nabokov's novel with no response, only deriving pleasure from that finesse? Colin McGinn is convinced that the last pages of Humbert's diary leave no doubt in the reader's mind as to the moral perspective of Nabokov's novel. ${ }^{47}$ In my view, there is no way of reading it as though we were not affected by the descriptions of Humbert's actions or the laconic but very clear remarks coming from Lolita's perspective. An attentive reader will find many hints influencing the judgement of the character, whose actions cannot be justified. Is it not true, however, that a great ethically significant aesthetic merit of this novel lies simply in how it elicits from us a certain form of anxiety prompting analysis and sharpening our sensitivity to evil? Perhaps its prescription is precisely to sow ferment in our minds and moral capabilities and lead us, through the thick tangle of Humbert's diary, to a just response to the work as a whole, in its aesthetic form and ethical content?

In response to this question, I suggest taking a look at Wayne Booth and Richard Rorty's interpretations containing numerous remarks that are of assistance in getting a proper read on Lolita. Where Booth's analysis is more subtle and concentrates on the risk, as manifested through the text, of Nabokov's concealment of his own moral judgement of Humbert Humbert, Rorty is inclined to let go of that risk. He sees it as a gesture to reinforce the connection between the difficulty posed by the novel and its great merit in exercising the reader's moral imagination.

As a representative of ethicism, Booth devotes much space to the problem of the reader's relationship with the literary work. He believes the relationship can be analogous to friendships we form in life with other human beings. Following Aristotle, he lists three types of relationships, founded on: pleasure, utility and good character. ${ }^{48}$ In literature we can have all three types of relationships, for in a good life there is room for all of them. Nonetheless, the most important role in a human person's moral life belongs to the type of relationship (with literature) grounded in moral character, followed by morally correct views and beliefs. Booth is convinced that readers reinforce their morality when dealing with such moral character, which does them no moral harm and does not lead them astray in moral terms. First, however, they need to discover what creates that moral character in the text and thus what constitutes the sense of life that the author may want to embody in the text. This sense of life is revealed by the utterances of the implied author, ${ }^{49}$ who is something else than the real author. The implied author is an instance different also from the narrator weaving the tale; an instance responsible for the moral and aesthetic principles presented in the literary work; 50 "the sense of life or the

\footnotetext{
${ }^{46}$ See also de la Durantaye (2007): 11: "The ideal response to a work of art is one that is indeed disinterested - but only slightly. It is a "disinterest" that does not exclude understanding and empathy. The fine line between personal and partisan - between idiosyncratic reaction and the cold evaluation of nothing but the fineness of a work's form - is one that is often extraordinarily difficult to draw. And it is precisely this line that Lolita, from its very beginning, traces."

${ }^{47}$ McGinn (1999): 37-38.

${ }^{48}$ Booth (1988). Booth discusses the matter in The Company We Keep, notably chapters 6 and 7.

${ }^{49}$ Booth (1961): 211ff.

${ }^{50}$ See Markiewicz (1995): 432.
} 
outlook that reveals itself in the structure of the text taken as a whole." ${ }^{51}$ Booth makes his distinction because readers often attribute to authors views that are expressed in the text, forgetting that the work is one of fiction. Sometimes, however, it is difficult to tell the one author from the other. This is especially true of works making use of first-person narration, such as Lolita, where the author's own view is obscured.

As Booth observes, the reader's reception of a literary work comprises a multitude of elements. Among those is the one mentioned by Ian Watt, whom Booth quotes as claiming that a novel usually takes an ambivalent form, often as a result of the fact that its coming to life constituted a reflection on the: "transition from the objective, social and public orientation of the classical world to the subjective, individualist and private orientation" 52 on life and literature. The novel began to accentuate "realism of presentation" in a world that was becoming increasingly ambiguous and relative, losing the "realism of assessment." 53 Other critics cited by Booth, such as Leon Edel, note that the cause of getting a wrong read on the text lies in the failure of communication between the author and the reader. The latter - in Leon Edel's words - should be understood as: "a failure of the two consciousnesses involved to establish a harmonious relationship. This happens often enough in life; there is no reason why we may not expect it to happen sometimes in our relationship to certain novels that we read." 54

Booth himself places much weight on the reader's intelligence and sensitivity, but he also believes authors should pay more attention to the explicit definition of their works' ethical attitudes. He perceives danger in unreliable narration, one that can expose readers to the various temptations of error: "Even when it represents characters whose conduct the author deeply deplores, it presents them through the seductive medium of their own self-defending rhetoric. It is consequently not surprising that reactions to such works have been marked with confusion and false accusations." 55 Booth appears to assert that the failure to read the implied author's suggestion arises both from the seductive rhetoric and from the reader's lack of ability to detach from it. He recalls the behavior of an editor of The New Republic, who, taking to heart the various irresponsible and mistaken readings of Lolita (more than the book itself), attacked it as though it had in principle been a defense of Humbert's conduct. In Booth's view the editor failed to understand the book but was also mistaken as to its probable effect on a multitude of readers. ${ }^{56}$

Booth wonders whether Lolita's more sophisticated readers were capable of catching the irony implied by Nabokov in many places of the novel, such as when Humbert Humbert - in his unlimited control of the rhetorical resource - expounds as follows:

I do not intend to convey the impression that I did not manage to be happy. Reader must understand that in the possession and thralldom of a nymphet the enchanted traveler stands, as it were, beyond happiness. For there is no other bliss on earth compa-

\footnotetext{
51 Nussbaum (1990c): 233.

52 Watt (1957): 176, 206. Cited after: Booth (1961): 387.

53 Booth (1961): 387.

54 Edel (1955): 139. Cited after: Booth (1961): 387.

55 Booth (1961): 388-389.

56 Ibidem: 391, fn. 11.
} 
rable to that of fondling a nymphet. It is hors concours, that bliss, it belongs to another class, another plane of sensitivity. Despite our tiffs, despite her nastiness, despite all the fuss and faces she made, and the vulgarity, and the danger, and the horrible hopelessness of it all, I still dwelled deep in my elected paradise - a paradise whose skies were the color of hell-flames - but still a "paradise" (Lolita, 168).

In Booth's opinion, Nabokov's irony, transpiring from Humbert Humbert's self-construction, is something that can be spotted by a mature reader, such as Booth's aforementioned Lionel Trilling, who disbelieves the narration from the very beginning. ${ }^{57}$

There is, however, in Nabokov's novel something due to which not all readers are capable of getting a proper read on it. It is the result of the seductive rhetoric employed by Humbert Humbert, who is capable of casting his actions in such a light and above all spinning such a tale as to succeed or almost succeed in white-washing them. For example, he attempts to place his relationship with Lolita in the perspective of the grand romances of human history, losing the moral value of his acts in the rhetoric. Humbert Humbert clearly professes taking comfort in verbiage. "I see nothing for the treatment of my misery but the melancholy and very local palliative of articulate art" (285). To him, words are a smokescreen obfuscating the true value of his conduct. However, as Booth would have it, Humbert's seemingly chiselled style is what is repugnant to a morally formed reader - it is that style which prevents Humbert Humbert's identification with Nabokov himself, who, implicitly, as the implied author, highlights the moral corruption of his protagonist, which then builds the moral attitude of the novel. Nabokov's novel gives the impression of having been written in such a way as for the rhetoric to be mustered in the defense of "evil" (on account of the character's suspicious narration), although a more attentive reader will despite all find it unacceptable due to having seen through the superficial layer. A less attentive reader, by contrast, will wonder at the final contrition coming from a man who is always convinced of the appropriateness of his actions and has even persuaded the readers to think the same way. Booth thus shows that the carrier of moral value can be not only what is being told but also how it is being told. In Booth's view, the ability to identify the latter aspect requires a certain discernment or maturity; hence the risk incumbent on the author..$^{58}$

\footnotetext{
57 Booth (1960): 390-391.

${ }^{58}$ Both Booth and Gaut represent ethicism and would certainly agree on what value to place on Lolita. What brings them together is how they look to the work itself for its moral foundation. Booth searches for it in the implied author's voice and Gaut on the attitude level. Gaut believes: "if we mean by the implied author simply the author as he manifests himself in the artistic acts in the work, then that ethical criticism has the implied author as its object is equivalent to the view defended here. There is no harm in talking of the implied author, if that is all that is meant. The problem is that the notion of the implied author is often used in a manner that strays far from this straightforward sense and ends up entangled in a conceptual thicket" (Gaut (2007): 75), for example in the unclear and ambiguous notion of a "second self", which is epistemically abstracted from the actual historical author and which - in Booth's opinion - is not necessarily relevant to the ethical evaluation of the work (which Gaut cannot agree with). He also believes the term "implied author" to be characteristic of intentionalism, i.e., a view in which: "what a work means is what its implied author intended it to mean" (Gaut (2007): 75), whereas in his opinion the "implied author's intentionalism" is a false position to take. Gaut's approach, consisting in searching for a work's ethical attitude in the internal structure of the text (prescriptions and attitudes existing in the text), in how certain things are presented therein, appears to be more objective and more apt from the perspective of defending ethicism.
} 
Rorty, by contrast, describes Nabokov as a writer who "gives us the details about what sorts of cruelty we ourselves are capable of, and thereby lets us redescribe ourselves." 59 In this way his novels can become a vehicle for moral change and for the development of humanity, even though Nabokov himself insisted that his aspiration was first of all to evoke aesthetic delight and emotional "tingles" in the audience. ${ }^{60}$ Rorty emphasizes that Nabokov, as a human being, was frightened the most by the thought that someone's suffering could elude him. Perhaps that was the force driving his creation of Humbert Humbert's character, so as to show that one can have artistic sensitivity altogether disconnected from moral sensitivity. Rorty is of the opinion that Nabokov would want these constituents of the definition of art to be inseparable and yet: "he has to face up to the unpleasant fact that writers can obtain and produce ecstasy while failing to notice suffering, while being incurious about the people whose lives provide their material." ${ }^{61}$ He is compelled to acknowledge that not every artist, including Humbert Humbert, is capable of sensing what is important to others or how important the imaginations and fantasies of others are, not just the artist's own. In creating characters that "are both ecstatic and cruel, noticing and heartless, poets who are only selectively curious, obsessives who are as sensitive as they are callous, ${ }^{\prime 62}$ Nabokov wants to avoid didacticism dealing in black-and-white categorizations, and in effect banalization arising from overly sharp use of words, where Rorty sees an opportunity for the development of the reader's understanding and imagination. Nabokov creates Humbert Humbert in such a way as to illustrate the nature of human capabilities and the limits to which one's humanity can be taken. He paints the picture of a "genius-monster - the monster of incuriosity," 63 of a man whose defining quality is "his inattentiveness to anything irrelevant to his own obsession." ${ }^{64}$ In so doing he aims to guide the reader toward a more vigilant perception of evil in oneself and in the world and a more sensitive way of responding to it.

Rorty points toward a very important example of how Nabokov conducts his narration, demonstrating that he does not leave the reader to his own devices. Instead, the author drops hints in the text that a perceptive reader should be able to pick up on, in a way. This refers to the fragment in which Lolita's deceased brother is mentioned and the one in which she speaks the words I have already quoted about the loneliness of dying. Rorty posits that Nabokov leaves it up to the reader to tie the two fragments together: Lolita's remarks about death and her recollection of having had a little brother who died. Moreover, Nabokov leaves it up to the reader to notice the fact that Humbert Humbert does not at all make the connection. He simply fails to notice it, such is his absorption in his obsessions. Nabokov, by contrast, expects that his ideal audience - he calls such readers, "a lot of little Nabokovs" 65 - will notice this fact, though later on he follows with numerous remarks in case, as he notes with regret, something could escape

\footnotetext{
59 Rorty (1988): xvi.

60 Ibidem: 152.

${ }^{61}$ Ibidem: 159.

62 Ibidem: 160.

63 Ibidem: 161.

64 Ibidem: 163.

65 Ibidem: 163.
} 
the audience's attention. That something is a reference to the child's death, which, as Rorty observes, is Nabokov's, "standard example of ultimate pain." 66 Therefore, contrary to Nabokov's assertion in the afterword ("I am neither a reader nor a writer of didactic fiction, and, despite John Ray's assertion, Lolita has no moral in tow" (Nabokov (1991b): 384)), there is a moral in his novel. As Rorty puts it: "the moral is not to keep one's hands off little girls but to notice what one is doing, and in particular to notice what people are saying. For it might turn out, it very often does turn out, that people are trying to tell you that they are suffering." 67 This is of importance to our relationships with others; hence, novels such as Lolita make a significant contribution to the development of our moral imagination. Rorty highlights Nabokov's practice in which "only what is relevant to our sense of what we should do with ourselves, or for others, is aesthetically useful," ${ }^{68}$ and "you cannot create a memorable character without thereby making a suggestion about how your reader should act." 69

The two positions - Booth's and Rorty's - do not, in my opinion, diverge from the interpretation of Lolita proposed by Gaut. They appear to corroborate and reinforce it. What, however, makes the merited-response argument a more suitable instrument for the analysis of Nabokov's novel is the searching for moral attitude and prescriptions in the novel's objective structure itself. Thus, Gaut's proposition rests on a more robust theoretical foundation, whereas Booth looks to the vague notion of an implied author different from the real author, and Rorty, though he too ultimately relies on the novel's structure, turns to Nabokov's life story for guidance to better understand his works. Booth laments how Humbert Humbert's manner of expressing himself is such as to give the impression of unlimited control of the novel's rhetorical resources. He claims that the protagonist seduces the readers with his rhetoric and that the implied author's remarks are too implicit. Rorty, by contrast, sees in that type of rhetoric a developmental opportunity for the reader.

Gaut, however, appears to add to their positions something more. He emphasizes the "two ways of being an unreliable narrator: either the narrator may be lying to his reader, knowing the truth himself; or he may be self-deceived, so that he is deceiving himself as well as his reader." ${ }^{70}$ Humbert Humbert, in his opinion, is unreliable in both ways, which is why his unreliability appears to be the driving influence on his seductive rhetoric. ${ }^{71}$ Moreover, one could see in Nabokov's novel two types of seductive rhetoric. One consists in an attempt to justify Humbert Humbert's immoral acts and another in an attempt to get us to accept the claim that Humbert's love for Lolita was mature and that he had to kill Quilty. Gaut believes that

\footnotetext{
${ }^{66}$ Ibidem.

${ }^{67}$ Ibidem.

${ }^{68}$ Ibidem: 167.

${ }^{69}$ Ibidem: 167. Rorty's interpretation was influenced by books about Nabokov highlighting the moral side of his novels - Rampton (1984) and Pifer (1980).

${ }^{70}$ Gaut (2007): 198-199.

${ }^{71}$ Ibidem: 199.
} 
the strategy is thus left as a trap in which to catch the heedless reader; but the clues are planted in the novel to signal that it is indeed a trap, and that we are not supposed simply to accept Humbert's actions and apparent redemption at the end at face value. Nabokov thus implicitly comments on Humbert's delusions and vanities and on the ease with which we can be seduced by his character. Humbert is manipulating us, partly consciously, partly out of the self-deception grounded on his vast egoism. And that view of what is happening fits neatly with Nabokov's own verdict in Humbert: a vain and cruel wretch who manages to appear "touching."72

According to Gaut, Nabokov's novel and (more notably) its second aforementioned seduction strategy show how easily we can be persuaded to accept attitudes we would be rejecting if we were thinking more attentively. Nabokov's Lolita, therefore, illustrates the manipulative force of rhetoric and art and also the yeoman's work that is the discovery of all the subtleties of the text, such as prescriptions and attitudes, which we must complete before we can judge the novel the way it deserves. This means that the reader's response to Lolita can only be appropriate once the reader responds to the work as a whole, aesthetically and ethically. ${ }^{73}$

\section{Ibidem: 201.}

${ }^{73}$ Although the goal of my text is not to discuss the merits of Gaut's argument but to take a look at Nabokov's novel through the prism of that argument and emphasize ethical reading, it would be expedient to recall Nils-Hennes Stear's discussion of the Merited Response Argument. Similarly to Gaut, he believes that an interesting counter-example for this argument can be found in a type of work he refers to as "seductive work" (Stear 2019; further quotations also come from this text). He notes that such type of works may attempt to elicit a response of the first, lower order (e.g., amusement) before reaching for a response of the second, higher order, whereby the inferior, first-order response would be rejected (e.g., shame for having burst out in laughter). He believes that if Gaut's argument were to be true, then "seductive works would be aesthetically flawed necessarily (...) For the second-order response to be merited, the first-order response it repudiates must be unmerited." Accordingly, in line with Gaut's argument, seductive work must attempt to evoke an unmerited response first and thus must be aesthetically flawed - a conclusion we could see as being counter-intuitive. It would be something different to claim that all seductive works are flawed as opposed to that they must be flawed, especially if they exemplify a high level of artistic skill. Despite this, Stear is not ready to reject Gaut's argument. He asserts: “the solution to this problem is, (...), to massage the Merit Principle a little to accommodate both the fact that seductive works do something that in most other contexts mars a work aesthetically, but also the fact that they get away with it." In his opinion: "all artworks operate under constraints limiting what they can achieve, but these limitations aren't always flaws." (Certain limitations may constitute a response to the audience's own shortcomings; for example children's literature is written to be understandable to unfledged readers and its resulting aesthetic deficiencies are irreproachable.) The source of Stear's proposed distinction is that which decides whether certain limitations constitute flaws and that which explains why seductive works avoid being flawed, even though they do have limitations. He proposes the following way out of the conundrum: "Whether limitations mar a work aesthetically, I suggest, depends on whether (a) the constraints imposing the limitations are (aesthetically) worthwhile, and (b) whether any limitations are only as large as such constraints require." From the combination of these two conditions a new principle emerges: "New Merit Principle: A work that attempts to elicit an unmerited response through artistic means is aesthetically flawed, unless the response is unmerited entirely because of aesthetically worthwhile constraints under which the work operates." This means that: "if pursuing seduction is worthwhile, attempting to elicit unmerited responses blemishes seductive works aesthetically only to the extent that their lack of meritedness exceeds whatever seduction requires." In this sense, Stear concludes: "successful seductive works attempt to elicit responses that are as merited as possible, conditional 
Novels such as Nabokov's Lolita appear at first glance to be a gauntlet thrown to ethicism as the view in which a work's moral character can sometimes be relevant to its aesthetic greatness, ${ }^{74}$ due to moral transgression, that is transgressing moral assumptions and questioning our existing moral beliefs. However, as Gaut notes, they ultimately end up providing a counterexample to didacticism or the extreme form of moralism. ${ }^{75}$ Thus Gaut is right in asserting that "the aesthetics for Nabokov includes the ethical; and (...) the aesthetic experience of this novel should embrace the ethical realm. If it is to be properly sensitive to the full richness of this wonderful work." 76 Gaut, though motivated by ethicism to add that a work suffers from an aesthetic flaw in so far as it has an ethical flaw that is aesthetically significant (and has some aesthetic merit in so far as it has an ethical merit that is aesthetically significant) ${ }^{77}$ does not believe Nabokov's Lolita to be an immoral work on the basis of its attitude. Nabokov's Lolita has aesthetic merit, for it has ethical merit of, in this case, also aesthetic significance in how Nabokov does not encourage us to adopt any simplistic moral stance, such as reading his novel only through the prism of one scheme of moral valuation. Instead, he encourages us to look at every word in the novel and base the response on our own judgment. In this sense it is not true what Nabokov himself says of his own work, that it "has no moral in tow" (Nabokov (1991b): 384). As McGinn observes: "Lolita does teach us many things about morality - as stories of human turpitude generally do. That is, it engages our moral sensibility and invites our moral judgment." 78 Simultaneously, Nabokov's work is an aesthetically resplendent work. However, one cannot on the one hand only respond to its aesthetic side (because of the context, which is liable to ethical judgment), and on the other hand, responding only to the ethical aspect would not be the full response this work merits. Of course, as McGinn observes, a naïve reader will only see the paedophiliac angle and probably not

on being seductive." In keeping with Stear's criterion, the conclusion must be that such a successful seductive work as Nabokov's appears to be an attempt to elicit reactions that are altogether merited. This also depends on its aesthetic seductiveness and whether that seductiveness is worthwhile. Nonetheless, I believe that only upon having considered the work as a whole, in both its aesthetic and ethical aspects, will we be able to give Lolita a fully merited response (thus, engagement with Humbert Humbert's seductive form of narration must be coupled with attention to the ethical nuance that I have highlighted). I concede that one of the components of this response is the awareness of some of the novel's limitations, which, however, need not necessarily be interpreted as flaws. It is important to answer Stear's question: "Is the seductive constraint worthwhile?" Doubtless, certain seductive works carry a great axiological strength consisting in how we take a look at ourselves in them as though in a mirror, thereby increasing our self-experience and capacity to understand others. As Stear himself responds: "I think the answer is obviously yes; with great skill, seductive works make one reflect on one's responses through a unique, rich, and edifying experience of one's own deficiency. What more could one ask of an artwork?"

${ }^{74}$ Mullin (2004): 254.

${ }^{75}$ See Gaut (1997): 194: “Vladimir Nabokov's great novel Lolita is at first sight a challenge to the ethicist cognitivist, rather than promising material for an illustration of the view. Indeed, it has often been held up as a counter-example to moralism about aesthetics." He goes on to make the following claim: "What Nabokov is against is pat, simplistic judgements; what he shows us in Lolita is that moral and psychological judgements need to be sensitive to the complexities of character, that we are prone to great simplifications and strangely biased judgements" (201-202).

76 Ibidem: 202.

77 Ibidem: 10.

${ }^{78}$ McGinn (1999): 38. 
even read to the end, where a more sophisticated audience will notice the interlacement of morality with art, agreeing this once with the opinion of Doctor Ray, who describes Humbert Humbert's diary as a "tragic tale tending unswervingly to nothing less than a moral apotheosis." 79 Nabokov's novel is not, therefore, immoral in its attitude, for although it depicts the immoral acts of the character-narrator (with the attitude and the content of a novel being two different things), it does not justify them. In saying that "it has no moral in tow," Nabokov wants to distance himself firmly from the didacticism of Balzac, Gorky or Mann. He does not, however, achieve the pure aesthetism characteristic of the fin de siècle. As Levine notes, the "very local palliative of articulate art" 80 is "(in part) the achievement of a redemptive moral sensibility." ${ }^{11}$ Hence, a multifaceted analysis is desirable, one reflecting both the aesthetic and the ethical aspect of the work. Nabokov's Lolita, in my opinion, merits such a response. ${ }^{82}$

\section{References}

Appel A. (1967), "Lolita: The Springboard of Parody," Wisconsin Studies in Contemporary Literature 8 (Spring): 204-224.

Appel A. (1991a), “Notes," [in:] The Annotated Lolita. Revised and Updated, A. Appel (ed.), Vintage Books, New York: 388-548.

Appel A. (1991b), "Preface," [in:] The Annotated Lolita. Revised and Updated, A. Appel (ed.), Vintage Books, New York: 3-8.

Booth W.C. (1961), The Rhetoric of Fiction, University of Chicago Press, Chicago.

Booth W.C. (1988), The Company We Keep. An Ethics of Fiction, University of California Press, Berkeley/Los Angeles/London.

Boyd B. (1991), Vladimir Nabokov: The American Years, Princeton University Press, Princeton.

Carroll N. (2000), „,Arts and Ethical Criticism: An Overview of Recent Directions of Research," Ethics 110: 350-387.

de la Durantaye L. (2007), The Style is Matter. The Moral Art od Vladimir Nabokov, Cornell University Press, Ithaca/London.

Edel L. (1955), The Psychological Novel: 1900-1950, Hart-Davis, London.

Edelstein M. (2008), "Teaching Lolita in a Course on Ethics and Literature," [in:] Approaches to Teaching Nabokov's Lolita, Z. Kuzmanovich, G. Diment (eds.), Modern Language Association of America, New York: 43-48.

Gaut B. (2007), Art, Emotion and Ethics, Oxford University Press, New York.

Gaut B. (1998), "The Ethical Criticism of Art," [in:] Aesthetics and Ethics. Essays at the Intersection, J. Levinson (ed.), Cambridge University Press, Cambridge/New York: 182-200.

Grygiel M. (2016), Gra w wartości - aksjologiczna strategia prozy Vladimira Nabokova, Wydawnictwo KUL, Lublin.

Harold J. (2006), "On Judging the Moral Value of Narrative Artworks," The Journal of Aesthetics and Art Criticism 64 (2): 259-270.

\footnotetext{
79 Nabokov (1991a): 81.

80 Ibidem: 352.

81 Levine (1995): 44.

82 The project is funded by the Ministry of Science and Higher Education within the program under the name "Regional Initiative of Excellence" in 2019-2022, project number: 028/RID/2018/19.
} 
Hume D. (2004), "Of the Standard of Taste," [in:] Critical Theory since Plato, H. Adams, L. Searle (eds.), third edition, Wadsworth Publishing, Boston: 323-332.

Levine P. (1995), “Lolita and Aristotle's Ethics," Philosophy and Literature 19 (1): 32-47.

McGinn C. (1999), “The Meaning and Morality of Lolita," The Philosophical Forum 30 (March): 31-41.

Nabokov V. (1991a), The Annotated Lolita. Revised and Updated, edited with preface, introduction and notes by A. Appel, Vintage Books, New York.

Nabokov V. (1973), Strong Opinions, McGraw-Hill, New York.

Nabokov V. (1991b), „On a Book Entitled Lolita," [in:] The Annotated Lolita. Revised and Updated, A. Appel (ed.), Vintage Books, New York: 380-386.

Nabokov V. (1980), "'Good Readers and Good Writers,” [in:] V. Nabokov, Lectures on Literature, Harcourt Brace Jovanovich, New York: 1-6.

Nussbaum M. (1990a), “'Finely Aware and Richly Responsible': Literature and the Moral Imagination," [in:] M. Nussbaum, Love's Knowledge. Essays on Philosophy and Literature, Oxford University Press, Oxford/New York: 148-167.

Nussbaum M. (1990b), "Introduction: Form and Content, Philosophy and Literature," [in:] M. Nussbaum, Love's Knowledge. Essays on Philosophy and Literature, Oxford University Press, Oxford/New York: 3-53.

Nussbaum M. (1990c), “Reading for Life," [in:] M. Nussbaum, Love's Knowledge. Essays on Philosophy and Literature, Oxford University Press, Oxford/New York: 230-244.

Phelan J. (2005), The Implied Author, Unreliability, and Ethical Positioning. "The Remains of the Day", [in:] J. Phelan, A Living to Tell About It. A Rhetoric and Ethics of Character Narration, Cornell University Press, Ithaca/London: 31-65.

Pifer E. (1980), Nabokov and the Novel, Harvard University Press, Cambridge.

Rampton D. (1984), Vladimir Nabokov: A Critical Study of the Novels, Harvard University Press, Cambridge.

Rorty R. (1989), Contingency, Irony and Solidarity, Cambridge University Press, Cambridge/ New York.

Stear N.-H. (2019), Seductive Artworks, URL = https://aestheticsforbirds.com/2019/01/17/ seductive-artworks/ [Accessed 21.06.2021].

Tokarczuk O. (2019), Nobel Lecture, URL = https://www.nobelprize.org/prizes/literature/2018/tokarczuk/lecture/ [Accessed 16.03.2021].

Trilling L. (1982), “The Last Lover - Vladimir Nabokov's Lolita," [in:] Nabokov: The Critical Heritage, N. Page (ed.), Routledge, Kegan \& Paul, London: 92-102.

Watt I. (1957), The Rise of the Novel, University of California Press, Berkeley (CA). 